\title{
Surface Roughness Effect in the Case of Welded Stainless Steel Corrosion Resistance
}

\author{
László TÓTH${ }^{1}$, Ferenc HARASZTI², Tünde KOVÁCS ${ }^{3}$ \\ ${ }^{1,3}$ Óbuda University, Bánki Donát Faculty of Mechanical and Safety Engineering, Department of Materials \\ Technology, Budapest, Hungary, toth.laszlo@bgk.uni-obuda.hu, kovacs.tunde@bgk.uni-obuda.hu \\ ${ }^{2}$ Óbuda University, Bánki Donát Faculty of Mechanical and Safety Engineering, Doctoral School of Safety \\ and Security Science, haraszti.ferenc@bgk.uni-obuda.hu
}

\begin{abstract}
It is known that fusion welding can cause a decrease in the corrosion resistance of the heat affected zone of unstabilized stainless steels. The reason for this problem is that the welding heat (in the heat affected zone (HAZ)) can cause chromium-carbide (Cr23C6) precipitation with the simultaneous reduction of chromium content at the local grain boundaries. The chromium content dictates the corrosion resistance level. The relationship between surface roughness and corrosion behaviour is well known. We sought to find the difference between the corrosion resistance and surface roughness relationship in the case of cold rolled stainless steel and in the case of heat treated (welding heat effect simulated) stainless steel [1-3].
\end{abstract}

Keywords: corrosion, precipitation, corrosion resistance, surface roughness, heat affected zone (HAZ).

\section{Introduction}

Stainless steels are very useful and popular in the industrial and civil engineering fields. There is a wide variety of stainless steels each having different properties and chemical composition. The austenitic stainless steels, due to their chemical composition, have high ductility and high corrosion resistance. Heat can cause some precipitation in the micro-structure, and this decreases the corrosion resistance level $[4,5]$.

The effects of surface roughness on the behaviour of steel in the presence of corrosion is well understood: Corrosion is more aggres-sive in the case of the high surface roughness steels than in case of those with low roughness $[6,7]$. Due to chemical composition, the cold rolling of steel sheets creates a thin corrosion-resistant passive layer. For aesthetic purposes, the building industry often requires grinding of the steel surface. This gives a nice finish to the sheet's surface. However, it also decreases the corrosion resistance as the protective layer is removed and the surface roughness changes.

Theoretically, the resistance layer renews rapidly on the surface of stainless steels, but this process is inhibited by the grinding pro-cess, causing the corrosion resistance to de-crease [8].

\section{The experimented steel}

\subsection{Austenitic stainless steel (1.4307)}

The chemical composition of the used aus-tenitic steel is shown in Tabel 1. High carbon affinity elements (eg. Ti, Ta, Nb) are not found in this chemical composition and the carbon contain is low.

The level of corrosion resistance of this steel is very high. The pitting resistance equivalent numbers (PREN) are calculated by the following most common equation, with the element weight as a percentage.

$$
\begin{aligned}
& P R E N=C r+3.3 \mathrm{Mo}+16 \mathrm{~N} \\
& P R E N=19.74
\end{aligned}
$$

\subsection{Surface preparation}

The tested sample surfaces were cleaned and ground according to grain size and the same chemical composition $\left(\mathrm{Al}_{2} \mathrm{O}_{3}\right)$ of the grinding 
Table 1. The used steel chemical composition in weight percentage (the rest is iron) (\%)

\begin{tabular}{|c|c|c|c|}
\hline $\mathbf{C}$ & $\mathbf{M n}$ & $\mathbf{S}$ & $\mathbf{P}$ \\
\hline 0.026 & 1.71 & 0.004 & 0.004 \\
$\mathbf{S i}$ & $\mathbf{N i}$ & $\mathbf{C r}$ & $\mathbf{N}$ \\
\hline 0.23 & 8.15 & 18.3 & 0.09 \\
\hline
\end{tabular}

papers. The used paper parameters are shown in the Table 2. The grinding process created different surface roughness in the case of the tested samples. The surface roughness $(\mathrm{Ra})$ of the samples was different, results shown in Table 2.

\subsection{Heat treating}

In the case of stainless steels, the fusion welding process is a very common joining technology. Fusion welding technology pro-duces a high heat effect during the joining process, which can change the microstructure in the heat affected zone (HAZ). We heated all samples for one hour at 800 ${ }^{\circ} \mathrm{C}$ and cooling was by air. .

Table 2. The used grinding paper parameters and the surface roughness of the ground sheets

\begin{tabular}{|c|c|c|c|c|}
\hline & $\mathbf{1}$ & $\mathbf{2}$ & $\mathbf{5}$ & $\mathbf{6}$ \\
\hline $\begin{array}{c}\text { Grinding } \\
\text { Paper }\end{array}$ & $\mathrm{P} 120$ & $\mathrm{P} 180$ & $\mathrm{P} 320$ & $\mathrm{P} 400$ \\
\hline $\begin{array}{c}\text { Surface } \\
\text { roughnes } \\
\text { Ra }(\boldsymbol{\mu m})\end{array}$ & 2.353 & 1.412 & 0.677 & 0.54 \\
\hline
\end{tabular}

\section{Corrosion tests}

The surface roughness and heat caused changes in both microstructure and corrosion resistance. This process was modelled by la-boratory experiments [9-11]. The tested samples were treated in FeIIICl solution (ASTM A 262), for 96 hours at $30^{\circ} \mathrm{C}$. Under this load, the sheets showed a weight loss that is measurable with analytical scales [12]. The measured weight loss volumes (g) are shown in the Table 3.

Tested samples were examined by microscopy and the results are shown in Figure 1-4. On the surface we detected pitting corrosion phenomena through visual testing, we used stereo microscopy, (100x magnification Figure 1-4) the figures show a $10 \times 10 \mathrm{~mm}$ area of the test samples.

We detected that in the case of the tested samples the unsuitable surface roughness caused reduced corrosion resistance. In the case of the heat treated samples, the heat treatment decreased corrosion resistance. (Figures 1-4) show the heat treated different surface roughness samples after corrosion tests. The corrosion was recognizable by visual testing and measurable by weight loss control.

\section{Conclusions}

We have concluded on basis of our experi-mental results that the corrosion resistance of the ground surface samples was lower than that of the cold rolled samples.

We also concluded that the corrosion weight loss in case of the heat treated samples was higher than in case of the others.

I. We found a relationship between surface roughness and weight loss in the tested samples.

II. Heat treating caused the decreasing of cor-rosion resistance.

Table 3. Weight loss of the tested samples

\begin{tabular}{|c|c|c|}
\hline Number & $\begin{array}{c}\text { Without heat } \\
\text { treating }\end{array}$ & Heat treated \\
\hline 1 & $0.4217 \mathrm{~g}$ & $0.9608 \mathrm{~g}$ \\
\hline 2 & $0.4005 \mathrm{~g}$ & $1.2904 \mathrm{~g}$ \\
\hline 5 & $0.4468 \mathrm{~g}$ & $1.0636 \mathrm{~g}$ \\
\hline 6 & $0.561 \mathrm{~g}$ & $1.7667 \mathrm{~g}$ \\
\hline
\end{tabular}

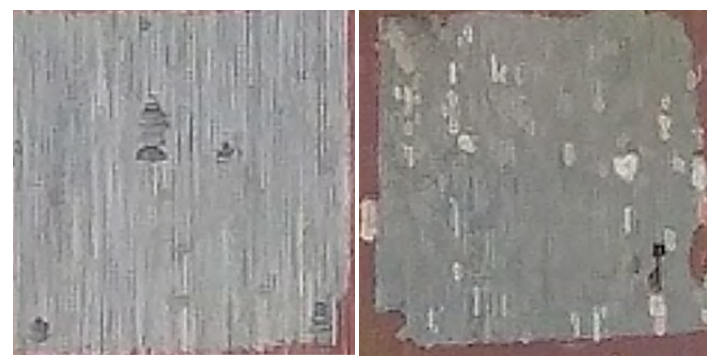

Figure 1. N. 1. samples: a) without heat treating, b) heat treated

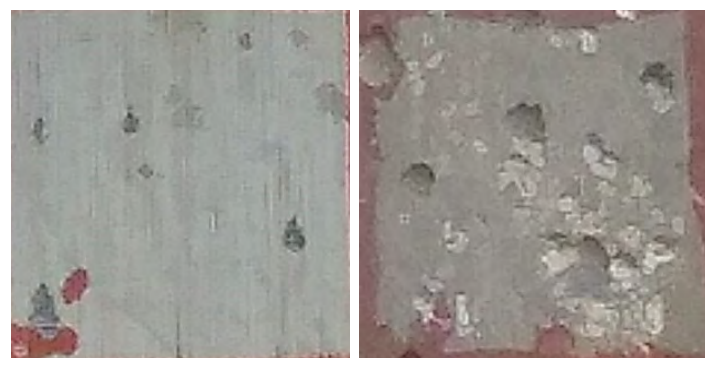

Figure 2. N. 2. samples: a) without heat treating, b) heat treated 

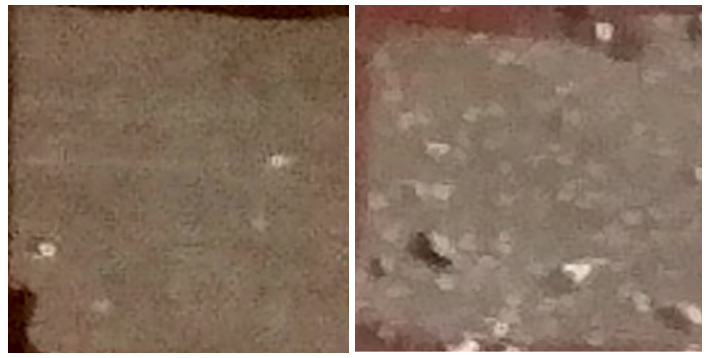

Figure 3. N. 5. samples: a) without heat treating, b) heat treated
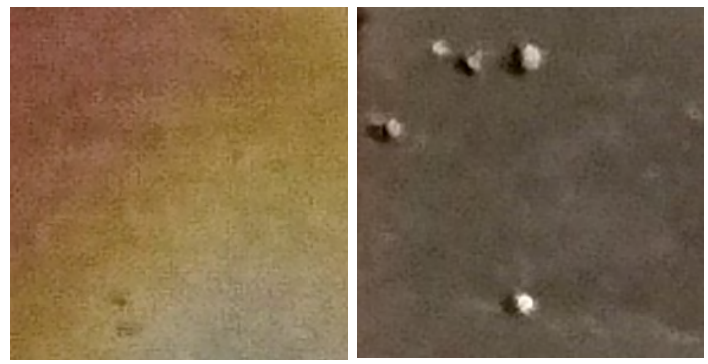

Figure 4. N. 6. samples: a) without heat treating, b) heat treated

III. We detected that in the case of the stain-less steel samples, surface grinding negatively affects corrosion resistance. Between surface roughness and corrosion resistance, we found a measurable correlation in the case of the tested samples.
IV. We carried out our test immediately after surface grinding and consequently, the protective surface layer was not able to re-cover in this short time. We assume that after surface grinding the protective layer can renew but requires a longer time.

These results are very important and there-fore further research is needed in order to better understand the surface properties of stainless steels.

\section{Acknowledgement}

The authors acknowledge the financial support provided by the Hungarian State and the European Union under the EFOP-3.6.1-16-2016-00010 project.

\section{References}

[1] Haraszti F., Kovács T.: Plastic deformation effect of the corrosion resistance in case of austenitic stainless steel. IOP Conference Series: Materials Science and Engineering, 175. (2017). https://doi.org/10.1088/1757-899X/175/1/012048

[2] Tedmon Jr. C. S., Vermilyea D. A., Rosolowski J. H: Intergranular corrosion of austenitic stainless steel. Journal of the Electrochemical Society, 118/2. (1971) 192-202. https://doi.org/10.1149/1.2407966

[3] Bagyinszki Gy., Bitay, E.: Hegesztéstechnika II. Berendezések és mérések. EME, Kolozsvár/Cluj, 2010.

http://hdl.handle.net/10598/15438

[4] Haraszti F., Kovács T.: Galvanic corrosion occurs heat experiments by thermographic camera. IOP

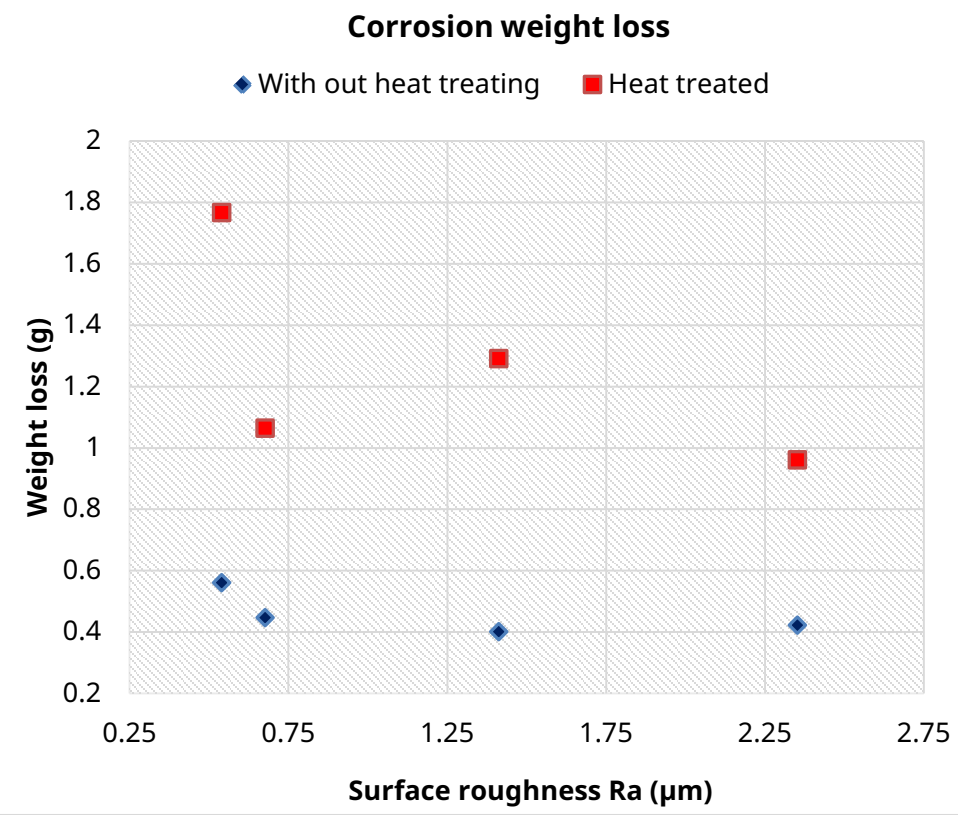

Figure 5. Corrosion effected weight loss in the case of heat treated and non-heat treated samples 
Conference Series: Journal of Physics: Conf. Series 1045. (2018).

https://doi.org/10.1088/1742-6596/1045/1/012016

[5] Haraszti F: Korrózió vizsgálatok alapjai. In: A XXI. Fiatal műszakiak tudományos ülésszak előadásai. Proceedings of the $21^{\text {th }}$ international scientific conference of youngth engineers. Müszaki Tudományos Közlemények 5., EME, Kolozsvár/ Cluj, Románia, 2016. 189-192. http://hdl.handle.net/10598/29058

[6] Kovács T., Kuzsella L.: High energy rate forming induced phase transition in austenitic steel. Journal of Physics Conference-Series, 790. (2017). https://doi.org/10.1088/1742-6596/790/1/012039

[7] Szigeti Á., Kovács-Coskun T.: Magas hömérsékletü korrozív közegben üzemelő acélrugó gyártástechnológiai tervezése. In: A XXI. Fiatal műszakiak tudományos ülésszak előadásai. Proceedings of the $21^{\text {th }}$ international scientific conference of youngth engineers. Müszaki Tudományos Közlemények 5., EME, Kolozsvár/Cluj, Románia, 2016. 377-380.

http://hdl.handle.net/10598/29111

[8] Dománkova M., Kocsisová E., Slatkovský I., Pinke P.: The microstructure evolution and its effect on corrosion properties of $18 \mathrm{Cr}-12 \mathrm{Ni}-2,5 \mathrm{Mo}$ steel annealed at $500-900{ }^{\circ} \mathrm{C}$. Acta Polytechnica Hungarica, 11/3. (2014) 125-137.

https://www.uni-obuda.hu/journal/Domankova_ Kocsisova_Slatkovsky_Pinke_49.pdf

[9] Nyikes Z., Rajnai Z.: Big Data, as part of the critical infrastructure. 2015 IEEE $13^{\text {th }}$ International Symposium on Intelligent Systems and Informatics (SISY), Subotica, Serbia, 2015. 217-222. https://doi.org/10.1109/SISY.2015.7325383

[10] Reti T., Kovacs T.: A phenomenological method for the prediction of damage accumulation processes under varying external conditions. In: Materials Science Forum, 414-415. (2003) 317-322. https://doi.org/10.4028/www.scientific.net/MSF.414415.317

[11] Tokody D., Flammini F.: Smart systems for the protection of individuals. Key Engineering Materials, 755. (2017) 190-197.

https://doi.org/10.4028/www.scientific.net/KEM. 755.190

[12] ASTM Standard Practice in A 262 for Detecting Susceptibility to Intergranular Corrosion in Austenitic Stainless Steels (1995). 